al Kimiya, Vol. 2, No. 1, Juni 2015

\title{
STUDI KOMPUTASI SENYAWA BERBASIS ANISIL INDOL DENGAN SENYAWA AKSEPTOR ASAM SIANOAKRILIK SEBAGAI SENSITIZER SOLAR SEL ORGANIK
}

\author{
Soni Setiadji, * Atthar LuQman Ivansyah, DAN Adi Bungsu Pribadi.
}

Jurusan Kimia, Fakultas Sains dan Teknologi, UIN Sunan Gunung Djati Bandung, Jl. A.H. Nasution No. 105 Cipadung, Bandung 40614

* email korespondensi: s.setiadji@gmail.com

ABSTRAK. Penelitian ini memprediksi sifat elektronik (diagram energi HOMO/LUMO, spektrum UV-Vis, dan rapatan orbital HOMO/LUMO) dari senyawa zat warna organik anisil indol / bi-3-n-heksiltiopen / asam sianoakrilik dan anisil indol / bi-3-n-heksiltiopen / katekol. Perhitungan komputasi dari ke dua senyawa tersebut[1], yang memodelkan sistem senyawa donor elektron / senyawa penghubung / senyawa penarik/akseptor elektron, dilakukan untuk membandingkan sifat elektronik ke dua senyawa penarik elektron tersebut agar dapat dipakai sebagai sensitizer dalam sel surya organik / sel surya tersensitasi zat warna. Dye Sensitized Solar Cell (DSSC) merupakan salah satu generasi sel surya yang banyak diteliti sampai saat ini. Sel surya ini menggunakan zat warna sebagai sensitizer dan menjadi sangat menarik untuk dikembangkan karena membutuhkan biaya produksi yang murah namum mampu menghasilkan kinerja yang cukup baik. Dalam penelitian ini perhitungan komputasi dilakukan menggunakan perangkat lunak Firefly, metoda DFT (teori fungsi rapatan) dan TDDFT (teori fungsi rapatan fungsi waktu), B3LYP/6-31G(d,p) untuk semua atom. Spektrum UV-Vis senyawa anisil indol / bi-3-nheksiltiopen / asam sianoakrilik hasil perhitungan komputasi memberikan serapan cahaya pada panjang gelombang $493,75 \mathrm{~nm}$ dengan kekuatan osilator 0,918. Sedangkan senyawa anisil indol / bi-3-n-heksiltiopen / katekol memberikan serapan cahaya pada panjang gelombang lebih pendek yaitu 410,53 nm dengan kekuatan osilator 1,4658. Diagram energi HOMO/LUMO untuk anisil indol / bi-3n-heksiltiopen / asam sianoakrilik dan anisil indol / bi-3-n-heksiltiopen / katekol memberikan band gap masing-masing sebesar $2,75 \mathrm{eV}$ dan 3,33 eV. Berdasarkan perhitungan energi, sistem zat warna dengan senyawa akseptor asam sianoakrilik memiliki energi yang lebih stabil dibandingkan dengan senyawa akseptor katekol.

Kata-kata kunci: senyawa sensitizer donorakseptor, dye sensitizer solar cells, asam sianoakrilik, katekol, teori fungsi rapatan fungsi waktu

\section{Pendahuluan}

Energi listrik merupakan energi primer, yang saat ini keberadaannya belum dapat digantikan oleh energi yang lain. Di Indonesia, kebutuhan energi listrik masih banyak dihasilkan oleh pembangkit listrik berbahan bakar fosil seperti minyak bumi, batu bara, dan lain-lain. Penggunaan bahan bakar fosil tersebut berpotensi menyebabkan masalah baru dalam lingkungan, yaitu pencemaran lingkungan dan memicu pemanasan global. Selain itu, di wilayah Indonesia masih banyak daerah yang belum mendapat pasokan listrik. Tercatat baru sekitar $65 \%$ wilayah Indonesia yang sudah mendapatkan pasokan listrik, dan sisanya masih menggunakan energi alam[8].

Dengan demikian, diperlukan suatu solusi yang efektif dan efisien baik secara aspek lingkungan maupun aspek ekologi yang dapat memberikan nilai positif bagi kelestarian lingkungan tanpa menyebabkan kerusakan di muka bumi ini. Sel surya cocok dikembangkan di Indonesia karena Indonesia merupakan negara yang memiliki iklim tropis dengan durasi penyinaran matahari yang cukup sepanjang tahunnya. Sel surya tersensitasi zat warna (Dye Sensitized Solar Cell, disingkat DSSC) merupakan salah satu pengembangan sel surya yang telah banyak diteliti sejak tahun 1991. Saat ini, sel surya tersensitasi zat warna merupakan sel surya yang paling efisien dan paling stabil[2,3,4,9].

Dalam perkembangannya, sel surya mengalami banyak perubahan untuk mendapatkan sel surya dengan kinerja yang lebih baik. Generasi pertama dari sel surya adalah sel surya yang menggunakan bahan silikon ( $\mathrm{Si}$ ). Pada sel surya yang menggunakan silikon, efisiensi yang dihasilkan sel surya 
tersebut berkisar 20\%. Kelemahan dari sel surya generasi pertama ini adalah bahan silikon yang digunakan relatif sulit untuk didapatkan, sehingga produksi sel surya generasi pertama tidak ekonomis karena ketersediaan silikon di alam relatif sedikit. Pada sel surya generasi kedua, digunakan polimer semikonduktor. Kelemahan dari sel surya generasi kedua ini adalah proses produksinya memerlukan teknologi yang relatif canggih dan biaya produksi yang relatif tinggi[3,5,9].

Mempertimbangkan adanya kelemahan pada sel surya generasi pertama dan kedua, maka dikembangkan DSSC yang memiliki beberapa keunggulan jika dibandingkan dengan sel surya generasi pertama dan generasi kedua. DSSC merupakan sel surya generasi ketiga, pengembangan dari sel surya generasi pertama dan generasi kedua. Kinerja DSSC salah satunya sangat dipengaruhi oleh sensitifitas zat warna yang digunakan. Sensitifitas zat warna tersebut mempengaruhi sifat optik dan elektrokimia pada DSSC, seperti spektrum absorpsi, dan sifat redoks. Kelebihan dari DSSC dibandingkan kedua sel surya yang dikembangkan sebelumnya adalah biaya produksi yang lebih murah. Kelemahan yang dimiliki oleh DSSC pada saat ini adalah efisiensi yang dicapai relatif kecil dibandingkan sel surya generasi pertama dan generasi kedua. Efisiensi yang kecil ini, salah satunya disebabkan oleh sensitifitas zat warna yang digunakan, dimana sampai saat ini terus dilakukan penemuan zat warna organik yang lebih baik untuk diaplikasikan pada DSSC[9].

Kajiyama et al berhasil mensintesis sistem zat warna organik sebagai sensitizer dalam DSSC[1]. Sistem zat warna tersebut terdiri dari senyawa donor / pendorong elektron, senyawa penghubung menggunakan bi-3-n-heksiltiopen, dan senyawa akseptor / penarik elektron berupa asam sianoakrilik[1]. Senyawa donor yang digunakan oleh Kajiyama et al., meliputi R-indol, R-karbazol dan Rindolin, dengan $\mathrm{R}$ adalah gugus etil, fenil, dan anisil[1]. Namun, dalam penelitian tersebut tidak dijelaskan secara lengkap hal-hal yang menjelaskan sifat optik dan elektrokimia dari senyawa tersebut. Pada penelitian ini akan dilakukan studi komputasi untuk mengevaluasi sifat elektronik senyawa anisil indol / bi-3-nheksiltiopen / asam sianoakrilik, serta mengganti senyawa penarik elektron asam sianoakrilik dengan katekol, yang tidak dilakukan dalam penelitian Kajiyama et al. Perhitungan komputasi terhadap ke dua sistem zat warna dengan memvariasikan sisi penarik elektron, selain untuk membandingkan sifat elektroniknya, juga untuk membandingkan kestabilan energi pembentukkan ke dua senyawa tersebut dan memprediksi kerapatan elektronnya.

Pada penelitian ini akan ditentukan perbedaan pita energi HOMO/LUMO dan spektrum serapan UV-Vis dari senyawa anisil indol / bi-3-n-heksiltiopen / asam sianoakrilik, serta senyawa anisil indol / bi-3-n-heksiltiopen / katekol dengan menggunakan metode teori fungsi rapatan (DFT), dan teori fungsi rapatan bergantung waktu (TDDFT). Perhitungan komputasi dilakukan dengan menggunakan perangkat lunak Firefly.

\section{Eksperimen}

Struktur senyawa hipotesis yang dihitung diberikan pada Gambar 1. Dalam penelitian ini perhitungan dilakukan dalam beberapa tahap dengan menggunakan metoda B3LYP dan basis set $6-31 G(d, p)[7]$. Koordinat senyawa yang akan dihitung dioptimasi menggunakan perangkat lunak Firefly.

Perhitungan pertama merupakan perhitungan dengan menggunakan metode DFT, dan output yang dihasilkan akan diolah lebih lanjut dengan perangkat lunak yang sama dengan menggunakan metode TDDFT. Untuk perhitungan DFT, dilakukan optimasi geometri, sedangkan untuk perhitungan TDDFT hanya menggunakan perhitungan satu titik. Dari hasil perhitungan TDDFT tersebut dapat diketahui spektrum UV-Vis dan perbedaan pita energi HOMO - LUMO dari masing-masing senyawa.

\section{Hasil dan diskusi}

Perhitungan komputasi menggunakan perangkat lunak firefly, menggunakan metoda B3LYP dan basis set 6-31G (d,p) yang sama untuk atom hidrogen $(\mathrm{H})$, karbon $(\mathrm{C})$, nitrogen $(\mathrm{N})$, oksigen $(\mathrm{O})$, dan sulfur $(\mathrm{S})$. Basis set 6$31 \mathrm{G}(\mathrm{d}, \mathrm{p})$ untuk semua atom tersebut akan menghasilkan data yang cukup teliti, dan juga mempertimbangkan ongkos perhitungan serta komputer yang digunakan. Perhitungan komputasi menggunakan metode DFT 


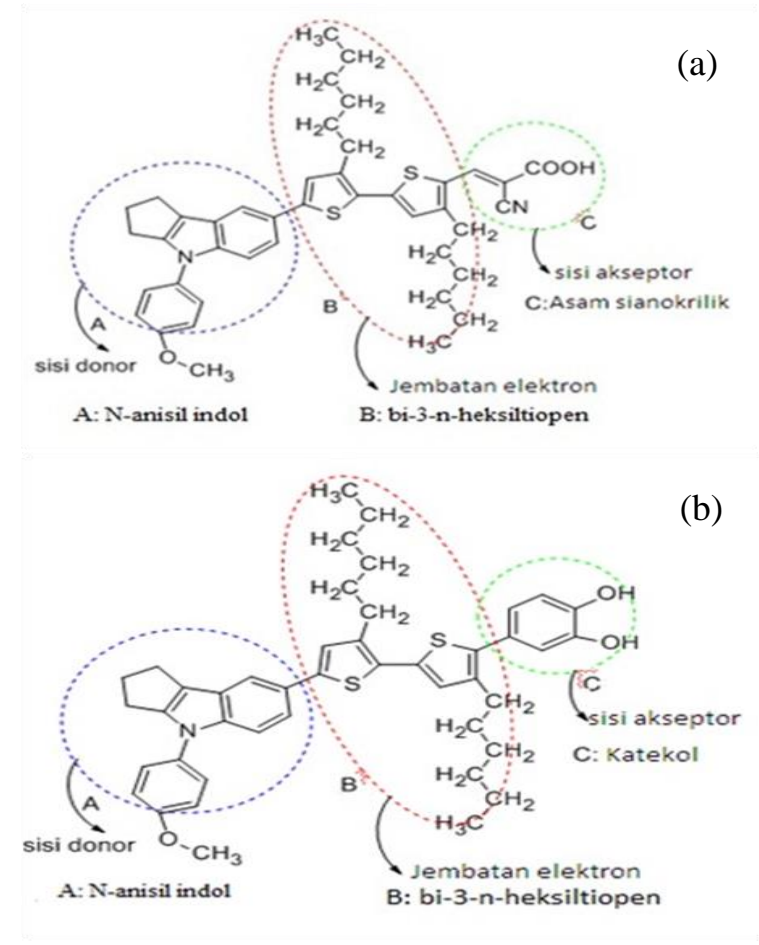

Gambar 1 Struktur (a) senyawa anisil indol / bi-3-n-heksiltiopen / asam sianoakrilik dan (b) senyawa anisil indol / bi-3-n-heksiltiopen / katekol.

memberikan keluaran berupa struktur senyawa teroptimasi, energi pada keadaan dasar, dan koordinat senyawa untuk perhitungan berikutnya. Perhitungan TDDFT memberikan data berupa spektrum UV-Vis, diagram tingkat energi HOMO/LUMO, celah energi, kerapatan elektron di orbital HOMO/LUMO, kekuatan osilator, dan tabel distribusi eksitasi HOMO/LUMO.

Kekuatan osilator akan sebanding dengan intensitas spektrum yang menjelaskan besarnya probabilitas elektron yang tereksitasi. Gambar 2 memperlihatkan spektrum UV-Vis dari senyawa anisil indol / bi-3-n-heksiltiopen / asam sianoakrilik dan senyawa anisil indol / bi3-n-heksiltiopen / katekol hasil perhitungan komputasi menggunakan perangkat lunak Firefly. Spektrum UV-Vis senyawa anisil indol / bi-3-n-heksiltiopen / asam sianoakrilik memberikan serapan cahaya pada panjang gelombang 493,75 $\mathrm{nm}$ dengan kekuatan osilator 0,918 . Sedangkan senyawa anisil indol / bi-3-n-heksiltiopen / katekol memberikan serapan cahaya pada panjang gelombang lebih pendek yaitu 410,53 $\mathrm{nm}$ dengan kekuatan osilator 1,4658 .

Dalam senyawa senyawa anisil indol / bi3-n-heksiltiopen / asam sianoakrilik, terdapat beberapa puncak dengan intensitas yang berbeda-beda. Puncak paling tinggi dihasilkan pada bilangan gelombang $20.253,31 \mathrm{~cm}^{-1}$ $(493.75 \mathrm{~nm})$ dengan kekuatan osilator sebesar 0,918, dimana puncak paling tinggi ini didominasi oleh eksitasi elektron dari HOMO $\rightarrow$ LUMO sebanyak 97\%. Selain itu, puncak tertinggi ini juga dihasilkan dari kontribusi minor dari eksitasi elektron $\mathrm{H}$ $1 \rightarrow$ LUMO sebanyak $2 \%$. Dalam hal ini yang

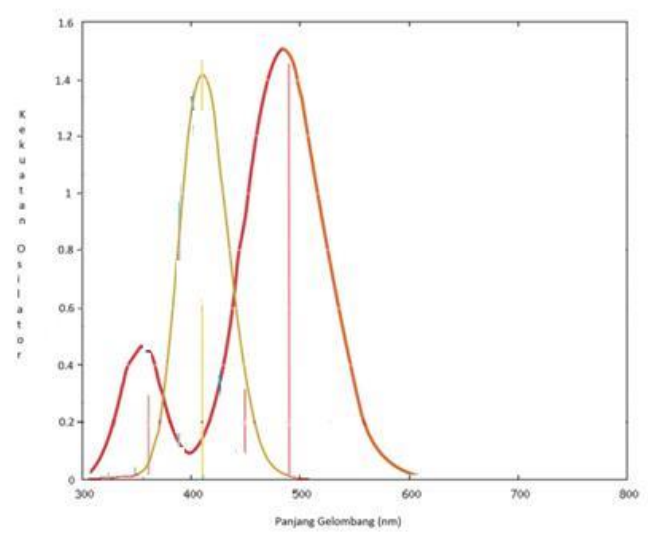

Gambar 2 Spektrum UV-Vis senyawa anisil indol / bi-3-n-heksiltiopen / asam sianoakrilik (kurva merah) dan anisil indol / bi-3-n-heksiltiopen / katekol (kurva kuning). 
menjadi pertimbangan adalah kekuatan osilator yang setara dengan kekuatan penyerapan cahaya oleh senyawa anisil indol / bi-3-nheksiltiopen / asam sianoakrilik, dimana menjelaskan peluang transisi elektronik elektron dari pita energi HOMO ke LUMO (kekuatan osilator bernilai 1). Tabel 1 memperlihatkan probabilitas eksitasi elektron secara lengkap pada senyawa anisil indol / bi-

Tabel 1. Probabilitas eksitasi elektron senyawa anisil indol / bi-3-n-heksiltiopen / asam sianoakrilik hasil perhitungan firefly

\begin{tabular}{|c|c|c|}
\hline $\begin{array}{c}\text { Keterangan } \\
\text { Kekuatan } \\
\text { osilator }\end{array}$ & $\begin{array}{c}\lambda \\
(\mathbf{n m})\end{array}$ & $\begin{array}{l}\mathrm{IO}, \mathrm{L}=\mathrm{LUMO}) \\
\text { Kontribusi } \\
\text { Utama }\end{array}$ \\
\hline 0.9180 & 493,75 & $\begin{array}{l}\mathrm{HOMO} \rightarrow \mathrm{LUMO} \\
(97 \%)\end{array}$ \\
\hline 0.2807 & 453.92 & H-1 $\rightarrow$ LUMO (96\%) \\
\hline 0.2687 & 365.49 & $\begin{array}{l}\text { H-2 } \rightarrow \text { LUMO }(86 \%), \\
H O M O \rightarrow L+1(11 \%)\end{array}$ \\
\hline 0.1272 & 341.78 & $\begin{array}{l}\mathrm{H}-3 \rightarrow \text { LUMO }(18 \%), \\
\mathrm{H}-2 \rightarrow \text { LUMO }(11 \%), \\
\mathrm{HOMO} \rightarrow \mathrm{L}+1(67 \%)\end{array}$ \\
\hline $\begin{array}{l}\text { Kekuatan } \\
\text { osilator }\end{array}$ & $\begin{array}{c}\lambda \\
(\mathbf{n m})\end{array}$ & $\begin{array}{l}\text { Kontribusi } \\
\text { Minor }\end{array}$ \\
\hline 0.9180 & 493,75 & $\mathrm{H}-1 \rightarrow$ LUMO $(2 \%)$ \\
\hline 0.2807 & 453.92 & $\begin{array}{l}\text { HOMO } \rightarrow \text { LUMO } \\
(2 \%)\end{array}$ \\
\hline 0.2687 & 365.49 & \\
\hline 0.1272 & 341.78 & \\
\hline
\end{tabular}

Tabel 2. Probabilitas eksitasi elektron senyawa anisil indol / bi-3-n-heksiltiopen / katekol hasil perhitungan firefly (Keterangan : $\mathrm{H}=\mathrm{HOMO}, \mathrm{L}=\mathrm{LUMO}$ )

\begin{tabular}{|c|c|c|}
\hline $\begin{array}{c}\text { Kekuatan } \\
\text { osilator }\end{array}$ & $\begin{array}{c}\lambda \\
(\mathbf{n m})\end{array}$ & $\begin{array}{l}\text { Kontribusi } \\
\text { Utama }\end{array}$ \\
\hline 1,4658 & 410,53 & $\begin{array}{l}\mathrm{HOMO} \rightarrow \quad \text { LUMO } \\
(99 \%)\end{array}$ \\
\hline 0,0085 & 355,71 & H-1 $\rightarrow$ LUMO (91\%) \\
\hline 0,0029 & 328,84 & $\begin{array}{l}\mathrm{H}-2 \rightarrow \text { LUMO }(14 \%) \\
\mathrm{HOMO} \rightarrow \mathrm{L}+1(74 \%)\end{array}$ \\
\hline 0,0046 & 326,06 & $\begin{array}{l}\mathrm{H}-2 \rightarrow \mathrm{LUMO}(41 \%), \\
\mathrm{HOMO} \rightarrow \mathrm{L}+1(21 \%), \\
\mathrm{HOMO} \rightarrow \mathrm{L}+2(32 \%)\end{array}$ \\
\hline $\begin{array}{c}\text { Kekuatan } \\
\text { osilator }\end{array}$ & $\begin{array}{c}\lambda \\
(\mathbf{n m})\end{array}$ & $\begin{array}{l}\text { Kontribusi } \\
\text { Minor }\end{array}$ \\
\hline 1,4658 & 410,53 & \\
\hline 0,0085 & 355,71 & $\begin{array}{l}\mathrm{HOMO} \rightarrow \mathrm{L}+2(2 \%) \\
\mathrm{HOMO} \rightarrow \mathrm{L}+3(3 \%)\end{array}$ \\
\hline 0,0029 & 328,84 & $\begin{array}{l}\mathrm{H}-1 \rightarrow \mathrm{L}+1 \quad(2 \%) \\
\mathrm{HOMO} \rightarrow \mathrm{L}+2(6 \%)\end{array}$ \\
\hline 0,0046 & 326,06 & \\
\hline
\end{tabular}

3-n-heksiltiopen / asam sianoakrilik hasil perhitungan TDDFT menggunakan perangkat lunak Firefly.

Dalam senyawa senyawa anisil indol / bi3-n-heksiltiopen / katekol, terdapat beberapa puncak dengan intensitas yang berbeda-beda. Puncak paling tinggi dihasilkan pada energi 3,0184 eV $(410,53 \mathrm{~nm})$ dengan kekuatan osilator sebesar 1,4658, dimana puncak paling tinggi ini hampir seluruhnya dihasilkan oleh eksitasi elektron dari $\mathrm{HOMO} \rightarrow$ LUMO sebanyak $99 \%$.

Orbital H-3 hingga HOMO berasal dari orbital $\pi$ (phi) pada gugus pendorong elektron. gugus anisil memiliki kontribusi yang tinggi pada orbital ini yang kemudian terdistribusi ke sistem konjugasi senyawa donor. Sementara itu, orbital LUMO hingga L+3 berasal dari orbital $\pi$ (phi) pada gugus penarik elektron dan memiliki kontribusi yang tinggi pada gugus anchoring $\mathrm{OH}$.

Diagram penyebaran elektron senyawa anisil indol / bi-3-n-heksiltiopen / asam sianoakrilik memperlihatkan penyebaran elektron dari orbital HOMO ke LUMO, mendistribusikan elektron dari sisi pendorong elektron menuju sisi penarik elektron. Pada orbital $\mathrm{H}-3$ hingga $\mathrm{H}-1$, penyebaran elektron
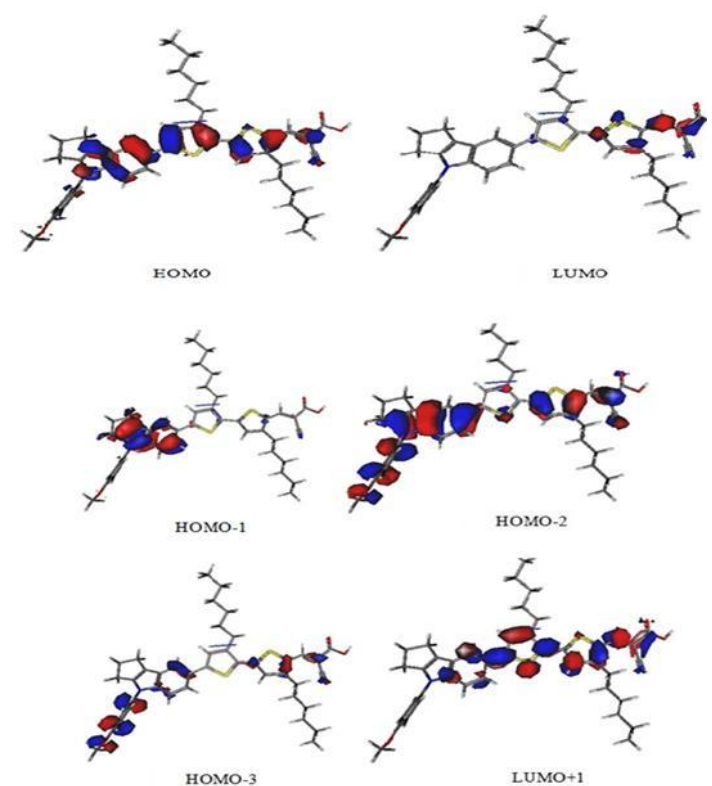

Gambar 3 Diagram penyebaran elektron hasil perhitungan komputasi senyawa anisil indol / bi-3-n-heksiltiopen / asam sianoakrilik pada orbital HOMO, LUMO, $\mathrm{H}-1, \mathrm{H}-2, \mathrm{H}-3$, dan L+1. 

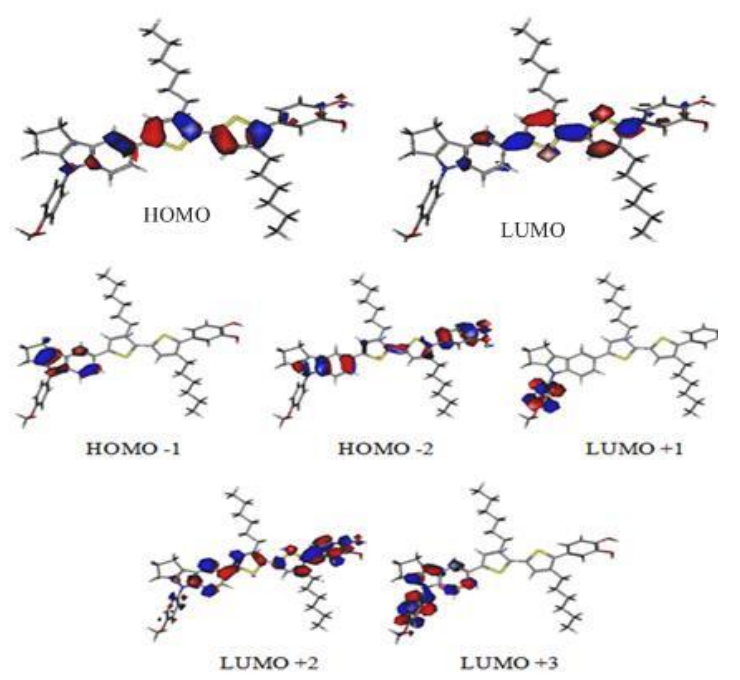

Gambar 4 Diagram penyebaran elektron hasil perhitungan komputasi senyawa anisil indol / bi-3-n-heksiltiopen / katekol pada orbital HOMO, LUMO, H-1, H-2, L+1, $\mathrm{L}+2$ dan $\mathrm{L}+3$.

dominan terdistribusi pada sisi pendorong elektron.

Diagram penyebaran elektron senyawa anisil indol / bi-3-n-heksiltiopen / katekol

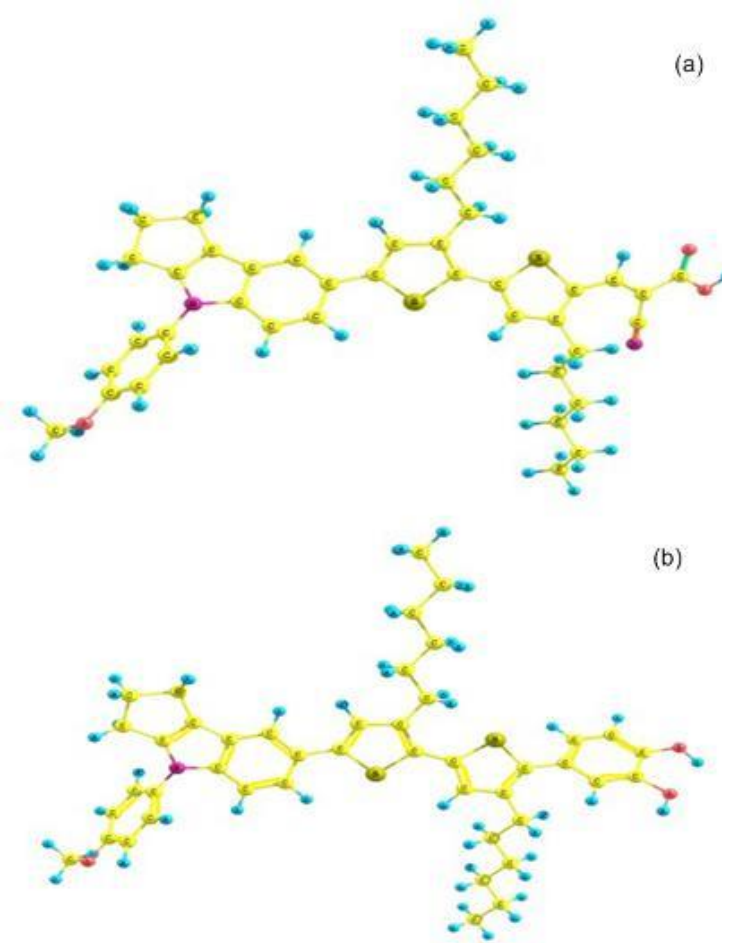

Gambar 5 (a) hasil optimasi geometri senyawa anisil indol / bi-3-n-heksiltiopen / asam sianoakrilik (b) hasil optimasi geometri senyawa anisil indol / bi-3-nheksiltiopen / katekol, dengan atom $\mathrm{H}, \mathrm{C}, \mathrm{N}$, $\mathrm{O}, \mathrm{S}$ beserta sistem terkonjugasi. memperlihatkan penyebaran elektron di orbital HOMO dan LUMO tidak terjadi distribusi elektron dari sisi pendorong elektron ke sisi penarik elektron. Orbital L+1 Pada senyawa ini, orbital L+1 masih terdistribusi di sisi pendorong elektron, dan menunjukkan perbedaan terhadap orbital $\mathrm{L}+1$ pada senyawa anisil indol / bi-3-n-heksiltiopen / asam sianoakrilik.

Diagram energi dari hasil perhitungan TDDFT senyawa anisil indol / bi-3-n-
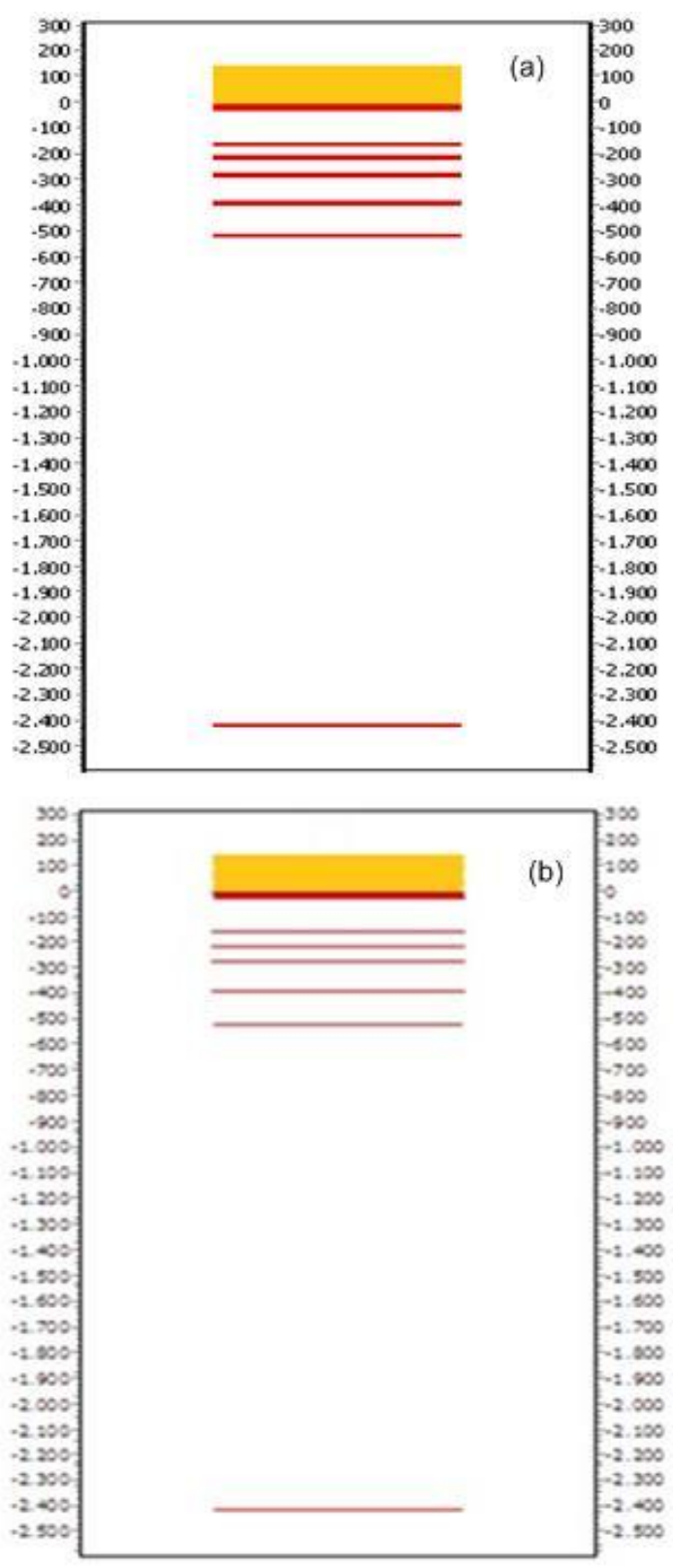

Gambar 6 (a) diagram energi senyawa anisil indol / bi-3-n-heksiltiopen / asam sianoakrilik (b) diagram energi senyawa anisil indol / bi-3-n-heksiltiopen / katekol, dengan HOMO (pita energi merah) dan LUMO (pita energi kuning). 
heksiltiopen / asam sianoakrilik dan anisil indol / bi-3-n-heksiltiopen / katekol ditunjukkan dalam Gambar 6. Diagram energi HOMO/LUMO untuk anisil indol / bi-3-nheksiltiopen / asam sianoakrilik dan anisil indol / bi-3-n-heksiltiopen / katekol memberikan band gap masing-masing sebesar 2,75 eV dan $3,33 \mathrm{eV}$.

Perbedaan pita energi yang dihasilkan merupakan selisih antara energi LUMO dengan energi HOMO. Nilai perbedaan pita energi yang semakin kecil, mengindikasikan bahwa semakin mudah suatu elektron berpindah dari tingkatan energi yang rendah, ke tingkatan energi yang lebih tinggi. Perpindahan elektron ini dapat terjadi dengan adanya pengaruh suhu dan penyinaran sinar matahari, dengan intensitas penyinaran yang sesuai dengan nilai band gap. Oleh karena itu, daya serap terhadap cahaya matahari dari suatu zat warna akan sangat ditentukan oleh besar kecilnya perbedaan pita energi yang dimiliki oleh suatu zat warna.

Berdasarkan hasil perhitungan struktur teroptimasi, senyawa anisil indol / bi-3-nheksiltiopen / asam sianoakrilik memiliki struktur lebih stabil dengan energi $60,97 \mathrm{~kJ} / \mathrm{mol}$ lebih rendah dari senyawa anisil indol / bi-3-nheksiltiopen / katekol.

\section{Kesimpulan}

Spektrum UV-Vis senyawa anisil indol / bi-3-n-heksiltiopen / asam sianoakrilik hasil perhitungan komputasi menggunakan firefly memberikan serapan cahaya pada panjang gelombang lebih jauh dibandingkan anisil indol / bi-3-n-heksiltiopen / katekol. Diagram energi HOMO/LUMO untuk ke dua senyawa tersebut secara berurutan memberikan celah energi masing-masing sebesar $2,75 \mathrm{eV}$ dan $3,33 \mathrm{eV}$. Transisi elektron dari ke dua senyawa tersebut dominan terjadi dari HOMO ke LUMO. Akan tetapi sumbangan transisi elektron HOMO ke LUMO dari senyawa anisil indol / bi-3-nheksiltiopen / katekol tidak menghasilkan distribusi elektron. Dari beberapa data yang memprediksi sifat elektronik ke dua senyawa tersebut, bahwa senyawa anisil indol / bi-3-nheksiltiopen / asam sianoakrilik lebih baik untuk digunakan sebagai sensitizer untuk solar sel organic (DSSC).

\section{Referensi}

[1] Kajiyama, et al. (2012): Organic dye with oligho-n-hexiylthiophene for dy-sensitized solar cell: relation between chemical struktur of donor photovoltaic performance, Dyes and Pigments, 92, pp. 1250-1256.

[2] Manzhos. S., Segawa. H., Yamashita. K. ((2011): A model for recombination in Type II dye-sensitized solar cells: Catechol-thiophene dyes., Chemical Physics Letters, 504, 230 235.

[3] Shah, A., Torres, P., Tscharner, R., Wyrsch, N., and Keppner, H. (1999): Photovoltaic Technology: The Case for Thin-Film Solar Cells., Science, 285, pp. 692-698.

[4] Brabec, C.J., Sariciftci, N.S., and Hummelen, J.C. (2001): Plastic Solar Cells., Advanced Functional Materials, 11, pp. 16-26.

[5] O'Regan, B., and Grätzel, M. (1991): A lowcost, high-efficiency solar cell based on dyesensitized colloidal $\mathrm{TiO}_{2}$ films, Nature, 353, pp. 737-740.

[6] Burgelman, M., Nollet, P., and Degrave, S. (2000): Modelling polycrystalline semiconductor solar cells., Thin Solid Films, pp. 527-532.

[7] Creutz, C., and Chou, M.H. (2008): Binding of Catechols to Mononuclear Titanium(IV) and to 1 - and 5-nm $\mathrm{TiO}_{2}$ Nanoparticles., Inorganic Chemistry Article, 47, pp. 3509-3514.

[8] Sánchez-de-Armas, R., Oviedo López, J., A. San-Miguel, M., Sanz, J.F., Ordejón, P., and Pruneda, M. (2010): Real-Time TD-DFT Simulations in Dye Sensitized Solar Cells: The Electronic Absorption Spectrum of Alizarin Supported on $\mathrm{TiO}_{2}$ Nanoclusters., Journal of Chemical Theory and Computation, 6, pp. 2856-2865.

[9] Daryanto. (2012). Energi Masalah dan Pemanfaatan Bagi Kehidupan Manusia. Yogyakarta : Pustaka Widyatama.

[10] Grätzel, M. (2003). Dye-sensitized solar cells. Journal of Photochemistry and Photobiology C: Photochemistry Reviews. 4, 145-153 